mag worden geacht. Hij stelt voor hem op zijn feest, den 20 Febr. a. s., van de levendige belangstelling van het Instituut te doen blijken door hem bij telegram daarmede geluk te wenschen.

Dienovereenkomstig wordt besloten.

Niets meer hierna aan de orde zijnde, wordt de Vergadering door den Voorzitter gesloten.

\title{
239ste BESTUURSVERGADERING,
}

GEHOUDEN 17 MAART 1883.

Tegenwoordig de heeren Kern, Kniphorst, Weitzel, Quarles van Ufford, Humme, Niemann, van Deventer, van Massehenbroek, Matthes en Wijnmalen. Afwezig met kennisgeving de heeren Juynboll en Bool.

Na opening der Vergadering heet de Voorzitter, Prof. Dr. Kern, de nieuwbenoemde bestuursleden, de heeren van Deventer, van Musschenbroek en Matthes, welkom, en terwijl hij van hunne belangstelling in de werkzaamheden van het Instituut overtuigd is, wit hij den wensch, dat door eendrachtige samenwerking der leden de bloei dier Instelling moge worden bevorderd.

Hierna worden achtereenvolgens voorgelezen de notulen van het verhandelde zoowel in de vorige Bestuursvergadering als in de Algemeene Vergadering, den 24sten Februari 1.1. gehouden; en terwijl de eerste werden goedgekeurd, worden de laatste voorloopig vastgesteld ter opneming in een der volgende afleveringen der Bijdragen. 
tal missives van de heeren Matthes en van Musschenbroek, beiden houdende bericht van de aanvaarding van het lidmaatschap van het Bestuur.

Voor kennisgeving aangenomen.

Aan de orde is de verkiezing van een Voorzitter, OnderVoorzitter, Penningmeester en Secretaris. Met groote meerderheid van stemmen worden achtereenvolgens de heeren Kern, Kniphorst en Wïnmalen tot Voorzitter, Penningmeester en Secretaris herkozen, die daarna verklaren zich de herkiezing te laten welgevallen.

In de plaats van het afgetreden lid Mr. W. Baron van Goltstein wordt tot Onder-Voorzitter gekozen de heer Weitzel, die de benoeming aanvaardt, onder dankzegging voor het in hem gesteld vertrouwen.

Door den Secretaris-Bibliothecaris wordt opgave gedaan van de sedert de vorige Vergadering ontvangen boekwerken, terwịl ingekomen zijn :

$a$. twee missives van de Koninklijke Akademie van Wetenschappen, te Amsterdam, een ten geleide van de jongste uitgaven der Akademie, de tweede houdende dankbetuiging voor de haar toegezonden afleveringen der Bijdragen van het Instituut.

$b$. eene missive van het Bestuur der Indologische Vereeniging te Delft, ten geleide van het Jaarboekje dier Vereeniging.

Plaatsing der werken in de Bibliotheek, onder dankbetuiging aan de inzenders.

De Voorzitter deelt mede, dat verder zijn ontvangen:

a. eene missive van de Anthropologische Gesellschaft in Wien, houdende het verzoek de voor haar bestemde werken en bijdragen te adresseeren aan het „k. k. naturhistorisches Hofmuseum in Wien".

Hiervan zal aanteekening worden gehouden.

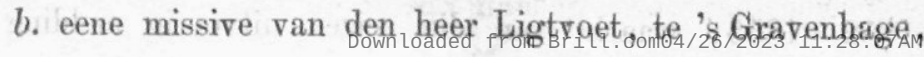


houdende bericht van het overlïden te Solo van zijn broeder K. W. H. Ligtvoet, lid van het Instituut.

Voor kennisgeving aangenomen.

c. eene missive van den hoogleeraar Dr. J. J. de Hollander, te Breda, houdende dankbetuiging voor de belangstelling hem vanwege het Bestuur van het Instituut betoond ter gelegenheid van zijne veertigjarige ambtsvervulling.

d. missives van de heeren F. H. P. van Alphen, J. S. A. van Dissel, H. E. D. Engelhard, A. R. W. Gey van Pittius, K. van der Heijden, J. de Koo, E. H. Lasonder, Mr. J. C. de Marez Oịens, P. M. Netscher, J. Semmelink, A. W. Sijthoff, Jhr. C. A. van Sypesteyn, P. E. Tegelberg, Mr. Ph. H. Verbeek en A. B. Zeverïn : allen houdende bericht van de anvaarding van het lidmaatschap van het Instituut.

e. eene missive van Prof. Mr. G. A. van Hamel, te Amsterdam, houdende kennisgeving, dat hij zich tot zijn leedwezen verplicht ziet het hem aangeboden lidmaatschap niet te aanvaarden.

$\mathrm{Al}$ deze missives, sub. $c, d$ en $e$ vermeld, worden achtereenvolgens voor kennisgeving aangenomen.

Ter tafel wordt gebracht eene missive van den Minister van Koloniën, van 16 Februari jl. $\mathrm{n}^{0}$. 34 , lett. $\mathrm{A}^{3}$, houdende mededeeling, dat, blijkens een uit Indië ontvangen bericht, noch ter Algemeene Secretarie noch in het archief van den Gouverneur van Sumatra's Westkust, afzonderlijke rapporten zijn aangetroffen omtrent de in de jaren 1852-1854 door den toenmaligen civielen Gezaghebber, de Vos, op het eiland Nias ondernomen reizen. Daarentegen is de Minister door de Indische Regeering in de gelegenheid gesteld om inzage te geven van een tweetal bundels, bevattende de dagregisters van den genoemden ambtenaar over de jaren

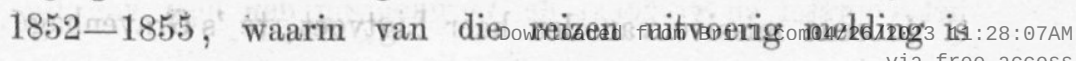


gemaakt. Mochten daarin gegevens voorkomen welke naar de meening van het Instituutsbestuur gepubliceerd verdienen te worden, dan zou hiertegen bij den Minister geen bezwaar bestaan, onder voorwaarde dat het te publiceeren opstel vooraf ter kennisneming aan de Regeering worde aangeboden. Ten slotte verzoekt de Minister de registers na gemaakt gebruik aan zijn departement terug te zenden.

Naar aanleiding van dit schrijven deelt de Secretaris mede, dat de daarin bedoelde stukken in goede orde ontvangen zijn, terwijl hij daaromtrent onverwijld is in overleg getreden met het correspondeerend lid von Rosenberg, op wiens raad vroeger de stukken waren opgevraagd.

$\mathrm{B} i \mathrm{j}$ onderzoek is het gebleken, dat de ontvangen dagregisters niet de door den heer von Rosenberg bedoelde bescheiden zijn. In de thans ontvangen twee bundels wordt wel gewag gemaakt van de reizen van den gezaghebber de Vos, doch telkens wordt daarin, zoodra het ethnografische bïzonderheden betreft, verwezen naar zijne algemeene verslagen en afzonderlijke missives aan den resident van Tapanoeli en het zijn juist die verslagen, waarvan de hernieuwde inzage en eventueele uitgave wenschelijk zou geweest zijn.

De dagregisters zelven bevatten echter grootendeels aanteekeningen omtrent criminele voorvallen, door den gezaghebber zelven onderzocht, waarvan enkele belangrijk kunnen worden geacht voor de kennis van land en volk. Daarenboven vindt men het itinéraire opgeteekend van de voormalige Commissie, bestaande uit de heeren van Nieuwenhuizen en von Rosenberg, wier arbeid, gelijk bekend is, reeds ettelijke jaren geleden door het Bataviaasch Genootschap van Kunsten en Wetenschappen werd uitgegeven, doch in die uitgave ontbrak tot dusver juist het bedoelde itinéraire.

Het komt den heer von Rosenberg voor, dat alleen dat itinéraire voor eene uitgave in aanmerking kan komen, waaraan men dan eene inleiding zou kunnen toevoegen bevattende eene korte aanwijzing van enkele feiten of gegevens, in de dagregisters voorkomende, die voor de geo- en ethnografie niet van belang ontbloot zijn. De Secretaris doet daartoe het voorstel en verzoekt de Vergadering den heer von Ro- 
senberg met de vervulling dier taak te belasten, en zoodra de heer von Rosenberg daarmede gereed is, alsdan het eventueel te publiceeren opstel vooraf ter kennisneming aan het Departement van Koloniën aan te bieden.

Dienovereenkomstig wordt besloten.

De heer Weitzel herinnert aan den reeds vroeger geuiten wensch dat aan de voor de aanstaande koloniale tentoonstelling in te zenden kaart van Junghuhn mogen worden toegevoegd eenige kaarten van Java, die vroeger hebben bestaan en waarvan men bij het uitbreken van den oorlog op Java gebruik had kunnen maken. Meer bepaald wïst hij op de kaarten, voorkomende $1^{0}$. in het werk van J. van den Bosch, „de Nederlandsche bezittingen in Azie, Amerika en Afrika, in derzelver toestand en aangelegenheden voor dit Rijk, te 's Hage 1818"; $2^{0}$. in de „Description géographique, historique et commerciale de Java et des autres îles de l'Archipel Indien", van F. I. Raffles en S. Crawfurd, 1824, en $3^{\circ}$. in de „Mémoire sur la guerre de l'île de Java" van Fr. H. A. de Stuers, in 1833 uitgegeven. Bedoelde werken met de daarbij behoorende kaarten zijn o. a. in de Bibliotheek van het Departement van Oorlog aanwezig en zouden, bij aanvrage, zeker voor de tentoonstelling beschikbaar kunnen worden gesteld. Hij stelt voor den Secretaris te machtigen daartoe het noodige te verrichten.

Dienovereenkomstig wordt besloten.

Naar aanleiding van de mededeelingen des heeren Weitzel wordt de aandacht der Vergadering gevestigd op het bestaan, tijdens den oorlog op Java, van inlandsche kaarten, waarvan het dusver niet bekend schijnt, waar zij gebleven zijn. Tevens wordt herinnerd aan een bestaand handschrift over den oorlog met Diepo Negoro, waaromtrent men gaarne nadere inlichtingen zou wenschen te ontvangen. De heeren van Musschenbroek en Weitzel verklaren zich bereid tot het samenstellen eener nota over beide aangelegenheden.

Door het bestuurslid Humme wordt de vraag geopperd, of een Javaansch leesboek, door den heer Rhemrew opge- 
steld, vanwege het Instituut zou kunnen worden uitgegeven. Uit de hierover gevoerde gedachtenwisseling blijkt dat men in beginsel niet gekant is tegen de uitgave van een leesboek, mits het blijke dat het niet van belang ontbloot is en particuliere krachten voor een uitgave er van te kort schieten.

Met het oog op het feit dat de uitgave van het tweede gedeelte van Bock's reisverhaal nog niet het licht heeft gezien, wordt, na eenige beraadslaging, besloten den Secretaris te machtigen daarover met den heer Robidé van der Aa in onderhandeling te treden.

De heer Quarles van Ufford vraagt den Secretaris, of de afzonderlijke afdrukken van de "Vragenreeks" van het Instituut door hem zijn verzonden naar de verschillende instellingen van onderwijs in de Indische taal-, land- en volkenkunde, zooals te Delft, Leiden, Breda en Willemsoord.

De Secretaris antwoordt dat alleen de verzending naar Indië heeft plaats gehad, doch vooralsnog geene gelegenheid te hebben gehad de Vragenreeks hier te lande te doen verspreiden, zich echter voorstellende daartoe eerlang over te gaan.

Door den Penningmeester wordt machtiging gevraagd $f 2000$ bij de bankiers Lissa en Kann te deponeeren. Dienovereenkomstig wordt besloten.

Niets meer hierna aan de orde zijnde wordt de Vergadering door den Voorzitter gesloten. 